\title{
Discrepancies between energy intake and expenditure in physically active women
}

\author{
BY KATHLEEN MULLIGAN AND GAIL E. BUTTERFIELD*† \\ Department of Nutritional Sciences, University of California, Berkeley, CA 94720, USA
}

(Received 30 October 1989 - Accepted 19 January 1990)

\begin{abstract}
Energy intake and expenditure in women runners and non-runners were assessed by weighed food records, evaluation of minute-by-minute activity diaries, and indirect calorimetry. All participants were adapted to their stated activity levels for at least 6 months and maintained a constant body-weight throughout their participation. Calculated daily energy intake equalled calculated expenditure in nonrunners (7300 (SD 1536) v. 7476 (SD 872) $\mathrm{kJ} / \mathrm{d}$ ), but calculated energy expenditure in women running about $54 \mathrm{~km} /$ week was found to exceed intake by more than $2700 \mathrm{~kJ} / \mathrm{d}$ (8259 (SD 1466) v. 10963 (SD 1367), $P<0.01$ ). The runners showed no evidence of compensating for the increased energy expenditure associated with running by engaging in lower-intensity activities during non-running time. Further, runners did not decrease energy expended at various activities. The findings suggest that women adapted to high levels of activity may possess mechanisms to maintain body-weight without significantly increasing energy intake.
\end{abstract}

Energy expenditure : Energy intake: Exercise: Physically active women

Exercise has gained increasing popularity in recent decades as an adjunct to weight control. In theory, if energy expenditure (EE) increases while energy intake remains constant, weight loss should occur. However, recent research exploring the relationship between exercise and energy balance suggests that the energy transactions which occur are more complex.

Persons in developing countries who are active in various agricultural and industrial occupations are reported to maintain their weight on energy intakes as low as $60 \%$ of their estimated requirements (Norgan et al. 1974; Edmundson, 1977; Bleiberg et al. 1981; de Guzman et al. 1984; McGuire \& Torun, 1984), and in the United States, recent studies have reported energy intakes in weight-stable women runners which were lower than expected, given their activity levels (Moore et al. 1983; Drinkwater et al. 1984; Marcus et al. 1985; Deuster et al. 1986; Myerson et al. 1987).

Adaptive changes proposed to explain the apparent ability of physically active persons to maintain their weight on energy intakes below theoretical need include the following: (1) compensatory changes in activity patterns and intensity of effort such that actual energy output is less than theoretical (Keys et al. 1950; Gorsky \& Calloway, 1983); and (2) decreases in basal, resting or post-prandial metabolic rates which may decrease overall energy needs (Apfelbaum et al. 1971; Prentice, 1984). Unfortunately, reports on the effect of training on resting metabolic rates (Poehlman et al. 1988; Bingham et al. 1989) and response to a meal (Davis et al. 1983; LeBlanc et al. 1984 a b) are conflicting, and there are no quantitative reports on daily activity patterns of athletes. Thus, the viability of these proposals cannot be evaluated. The following experiment was performed to determine (a) if persons adapted to strenuous physical activity ingest less energy than would be predicted

* For reprints.

$\uparrow$ Present address: Geriatric Research, Education and Clinical Center, 182B, Palo Alto Veterans Administration Medical Center, Palo Alto, CA 94304, USA. 
by their activity; (b) if such individuals compensate for periods of strenuous exercise by spending the rest of their time in activities requiring lower levels of energy expenditure than sedentary controls; and (c) if such individuals expend less energy at rest and at given tasks than non-exercising individuals. In light of recent evidence associating athletic amenorrhoea with low energy intakes and decreased bone density (Drinkwater et al. 1984; Marcus et al. 1985), it seemed particularly important to explore these questions in female athletes.

\section{METHODS}

\section{Subjects}

Twenty-one female runners and non-runners were selected from applicants recruited by newspaper and public service announcements. Selection was based on information obtained from dietary and exercise history questionnaires and personal interviews. Participants were between the ages of 19 and 41 years, had no history of serious illness, were within $10 \%$ of their ideal body-weight, had no history of major weight control problems or eating disorders, did not smoke or use oral contraceptive agents, and were premenopausal. Women in the control or non-runners groups did not run or regularly engage in any other form of strenuous exercise. Women recruited as runners ran as their primary form of exercise and had been running at their current levels for at least 6 months before participation in the study. Many of the runners also engaged in strenuous exercise other than running, such as cycling or swimming, which presumably contributed to their fitness. Duplicate measures of estimated maximal oxygen consumption $\left(\dot{V}_{\mathrm{o}_{2}, \max }\right)$ revealed there to be two distinct groups of runners: those with $\dot{V}_{\mathrm{o}_{2}, \max }$ less than $58 \mathrm{ml} / \mathrm{kg}$ per min, called 'moderately active', and a group with $\dot{V}_{\mathrm{O}_{2} \text {, max }}$ greater than $63 \mathrm{ml} / \mathrm{kg}$ per min, referred to as 'very active'.

Each woman's involvement spanned two menstrual cycles. All women agreed to adhere to their regular food intake and activity patterns, and to maintain their current training programmes. Each subject was informed verbally and in writing of the procedures to be used, and voluntarily consented in writing to the prescribed protocol, which had received previous approval by the University of California, Berkeley, Committee for the Protection of Human Subjects. On completion of her participation, each woman received a computer analysis of her diet, information on estimated fitness and body composition measures, a small monetary compensation, and the opportunity to avail herself of nutritional counselling.

\section{Measurements}

Subjects kept daily written records of the following throughout their participation: (1) body-weight (to document maintenance of a steady-state over the course of participation); (2) distance and duration of all runs (to monitor total weekly distance and verify pace and steady training state), (3) all other exercise, such as bicycling, swimming and acrobics; (4) body temperature, taken orally on awakening (to identify time of ovulation).

During three consecutive $24 \mathrm{~h}$ periods each week of the 2 month period, the women recorded all foods and beverages consumed (other than water), as well as all activities. They were instructed to record each entry at the time of occurrence, using microcassette tape recorders. Two subjects found that keeping ongoing written diaries was better suited to their lifestyles. Previous research has shown no significant differences between the use of taped or written records to calculate daily energy intake (Todd et al. 1983) or expenditure (Gorsky \& Calloway, 1983). Participants were instructed to weigh portions whenever possible using diet scales, and to describe and estimate portion sizes on the few occasions when direct measurement was impossible. They were also instructed to record the time and body position for each activity change throughout the recording period. Participants were questioned by the investigator to verify and clarify the information provided both when 
reports were delivered and when they were analysed. Each week's recording covered a different set of $3 \mathrm{~d}$, so that by the end of participation, each subject had provided at least two records for each day of the week. In this way it was possible to account for weekday-weekend differences in intake or activity patterns.

On two occasions, each woman underwent a series of tests of energy expenditure and body composition. To control for reported differences in energy expenditure over the course of the menstrual cycle (Solomon et al. 1982), half the participants in each activity group were tested 7-10 d following the day on which ovulation was assumed to have occurred, based on oral temperature recordings; the other half were tested $7-10 \mathrm{~d}$ following menses.

EE was measured by open-circuit indirect calorimetry as follows.

1. Resting metabolic rate $(R M R)$. The women were instructed to consume only water after 21.00 hours of the day preceding the measurement. They were told to do no work or exercise before reporting to the test site by 08.00 hours. On arrival, each participant rested on a bed in a private bedroom for $30 \mathrm{~min}$. A noseclip and mouthpiece were then positioned on the subject, and she was allowed to adapt to the apparatus for $10 \mathrm{~min}$. A $10 \mathrm{~min}$ resting breath sample was then collected in a Douglas bag.

2. Routine activities. Breath samples were also collected from the subjects while they sat quietly, walked a set flat course, walked a set course up and down a flight of stairs and engaged in intermittent standing activity, called 'milling around'. The walking and 'milling around' activities were performed at levels of intensity selected by the individual. Participants were timed while walking the set courses. Each activity was performed for a 5 min adaptation period before a 2 min breath sample was collected by Douglas bag.

3. Cycle ergometer. Participants pedalled on a stationary bicycle (Uniwork Ergometer Model 844; Quinton Instruments, Seattle, WA) at a series of fixed, increasing work loads. Electrocardiogram (ECG) electrode pads were placed on three locations on the upper torso, and heart rate was monitored throughout the cycle ergometer exercise (1500B Electrocardiogram; Hewlett Packard, Palo Alto, CA). Work load was increased incrementally every $10 \mathrm{~min}$ until the participant reached a heart rate equivalent to $70 \%$ of her estimated maximal heart rate ( 220 beats/min minus age (years)) (Brooks \& Fahey, 1984). Expired gases were analysed during the final 2 min at each work load.

The volumes of expired air collected by Douglas bag during the RMR, walking and 'milling-around' procedures were measured by a turbine-type gas meter (DTM-115; Singer Corp, American Meter Division, Philadelphia, PA); volumes of expired gases monitored during sitting and cycling were measured by pneumoscan (S-300 Spirometer; K.L. Engineering Co., No. Hollywood, CA). Expired air was analysed for concentrations of $\mathrm{O}_{2}$ by $\mathrm{S}-3 \mathrm{~A} \mathrm{O}_{2}$ analyser (Ametek Inc., Pittsburgh, PA), and carbon dioxide by LB-CO analyser (Beckman Instruments, Anaheim, $\mathrm{CA}$ ). $\mathrm{O}_{2}$ and $\mathrm{CO}_{2}$ analysers were calibrated to reference gases at the start of each analysis period, and the volume meter was calibrated to the pneumoscan. All gas volumes were corrected to standard conditions of temperature and pressure.

Body composition was estimated by hydrostatic weighing (Behnke \& Wilmore, 1974). Residual lung volume was estimated using the nitrogen-washout technique (Wilmore, 1969).

\section{Calculations}

Calculations of $\mathrm{CO}_{2}$ produced $\left(\dot{V}_{\mathrm{CO}_{2}}\right), \mathrm{O}_{2}$ consumed $\left(\dot{V}_{\mathrm{O}_{2}}\right)$, respiratory exchange ratio $(R)$ and metabolic rate $(M R)$ were performed by microcomputer; $M R$ was calculated with the formula of Weir (1949) which assumes that protein metabolism contributes one-eighth of total energy produced:

$$
M R=\left(3.9 \times \dot{V}_{\mathrm{O}_{2}}\right)+\left(1 \cdot 1 \times \dot{V}_{\mathrm{CO}_{2}}\right) .
$$


$\mathrm{O}_{2}$ consumption and heart rate values collected during the cycle ergometer exercise at submaximal work loads were used to estimate $\dot{V}_{\mathrm{O}_{2}, \max }$ by the method of Astrand and Rhyming, making prescribed adjustments for age (Âstrand \& Rodahl, 1970).

Percentage body fat $(\% \mathrm{BF})$ calculations were based on the formula of Siri (1956). Fatfree mass (FFM) was calculated by subtracting fat weight from body-weight.

Taped food-intake records were transcribed, coded and analysed using the University of California, Berkeley, Minilist data base and a cross-referencing system developed by Murphy (1984). Activity records were individually coded using a system of seventy-three activity codes developed by the investigators to reflect the diverse activities of the participants (see Appendix). Each activity was associated with an energy factor (EFACT), which reflects the energy expenditure of each activity, expressed as a multiple of RMR. The EFACTs were gathered from information contained in Passmore \& Durnin (1955), Durnin \& Passmore (1967), Howley \& Glover (1974), Briggs \& Calloway (1979), and Gorsky \& Calloway (1983). In the case of a few activities, such as windsurfing, published values could not be found, and EFACTs were deduced from activities estimated to be of similar intensity. The activities of each subject were aggregated so that all minutes of activity in each category for $1 \mathrm{~d}$ became one record; the time-periods (min) in each activity category were then multiplied by the corresponding EFACT. The sum of all these products was then divided by $1440 \mathrm{~min} / \mathrm{d}$ to arrive at an activity index (AI), the expression of that day's estimated energy expenditure as a multiple of the RMR. Its formula would be expressed as follows:

$$
\mathrm{AI}=\frac{\sum(\text { time-period }(\mathrm{min}) \text { at each activity } \times \text { appropriate EFACT })}{1440 \mathrm{~min} / \mathrm{d}} .
$$

A non-running activity index (NRAI), the average daily EFACT of all activities other than running, was similarly calculated:

$$
\mathrm{NRAI}=\frac{\sum(\text { time-period }(\mathrm{min}) \text { at each non-running activity } \times \text { appropriate EFACT })}{\text { total non-running } \mathrm{min} / \mathrm{d}} .
$$

Individual daily $\mathrm{AI}$ and measured RMRs were used to express daily EE by the following calculation:

$$
\mathrm{EE}(\mathrm{kJ} / \mathrm{d})=\mathrm{AI} \times \mathrm{RMR}(\mathrm{kJ} / \mathrm{min}) \times 1440 \mathrm{~min} / \mathrm{d} .
$$

Also calculated was the total period (min) spent per day in each of six major activity categories: sleeping, lying down, sitting, standing, running and other exercise.

Data were analysed by one-way analysis of variance, linear regression and Student's $t$ test. Tukey's range test was used for multiple comparisons of group means at an $\alpha$ value of 0.05 . Analysis of activity data and all statistical analyses were performed using the SPSS$\mathrm{X}$ software routines (Nie et al. 1983).

\section{RESULTS}

\section{Group characteristics}

All participants in the study were intelligent, articulate, highly motivated and compliant. Many had previous experience of keeping weighed food records and all responded positively to training and guidance in data collection methods. The three groups described earlier did not differ significantly in age or body-weight, although $\% \mathrm{BF}$ was significantly lower and FFM was significantly higher in the very active runners $(P<0.002$ and $P<0.02$ respectively), when compared with the moderately active runners and non-runners (see 
Table 1. Group characteristics for physically active women

(Mean values and standard deviations)

\begin{tabular}{|c|c|c|c|c|c|c|}
\hline \multirow[t]{2}{*}{$\begin{array}{l}\text { Activity level }{ }^{*} \ldots \\
n \ldots\end{array}$} & \multicolumn{2}{|c|}{$\begin{array}{c}\text { Non-runners } \\
5\end{array}$} & \multicolumn{2}{|c|}{$\begin{array}{c}\text { Moderately } \\
\text { active runners } \\
9\end{array}$} & \multicolumn{2}{|c|}{$\begin{array}{c}\text { Very active } \\
\text { runners } \\
7\end{array}$} \\
\hline & Mean & SD & Mean & $\mathrm{SD}$ & Mean & SD \\
\hline Age (years) & $30 \cdot 6$ & 5.6 & $37 \cdot 0$ & $4 \cdot 2$ & $29 \cdot 8$ & $8 \cdot 0$ \\
\hline Initial wt $(\mathrm{kg}) \dagger$ & $54 \cdot 8$ & $5 \cdot 0$ & $52 \cdot 2$ & $5 \cdot 1$ & $54 \cdot 5$ & $4 \cdot 4$ \\
\hline Final wt $(\mathrm{kg}) \dagger$ & $54 \cdot 3$ & $4 \cdot 5$ & $52 \cdot 2$ & $5 \cdot 2$ & $54 \cdot 8$ & $4 \cdot 5$ \\
\hline Wt at UWW $(\mathrm{kg}) \dagger$ & $53 \cdot 9$ & 5.6 & 51.9 & $5 \cdot 9$ & $55 \cdot 0$ & $4 \cdot 7$ \\
\hline Percentage body fat & $26 \cdot 0^{a}$ & $4 \cdot 7$ & $21 \cdot 9^{\mathrm{a}}$ & $3 \cdot 2$ & $16 \cdot 7^{b}$ & $3 \cdot 8$ \\
\hline Fat-free mass $(\mathrm{kg})$ & $39 \cdot 7^{a}$ & $2 \cdot 8$ & $40 \cdot 5^{\mathrm{a}}$ & $4 \cdot 2$ & $45 \cdot 8^{\mathrm{b}}$ & $4 \cdot 1$ \\
\hline$\dot{V}_{O, \max }(\mathrm{ml} / \mathrm{kg}$ per $\min )$ & $41 \cdot 7^{\mathrm{a}}$ & $8 \cdot 0$ & $51 \cdot 6^{\mathrm{b}}$ & $3 \cdot 6$ & $66 \cdot 8^{\circ}$ & $7 \cdot 5$ \\
\hline Distance run/week $(\mathrm{km})$ & 一 & & $39 \cdot 5$ & $10 \cdot 1$ & $54 \cdot 4$ & $26 \cdot 4$ \\
\hline Usual running pace $(\mathrm{min} / \mathrm{km})$ & - & & $5 \cdot 8^{\mathrm{a}}$ & $0 \cdot 8$ & $4 \cdot 9^{\mathrm{b}}$ & 0.4 \\
\hline
\end{tabular}

UWW, underwater weighing; $\dot{V}_{\mathrm{O}_{2} \text { max }}$, estimated maximal oxygen consumption.

s,b,e Means in horizontal rows with different superscript letters were significantly different $(P<0 \cdot 05)$.

* Moderately active, $\dot{V}_{\mathrm{O} \text { max }}<58 \mathrm{ml} / \mathrm{kg}$ per min; very active, $\dot{V}_{\mathrm{O}_{2} \text { max }}>63 \mathrm{ml} / \mathrm{kg}$ per min.

$\dagger$ Initial and final weights for each subject are means of first $7 \mathrm{~d}$ and final $7 \mathrm{~d}$ of self-reported weights. Weight at UWW was measured at the test site.

Table 2. Resting metabolic rates ( $R M R)$ of physically active women

(Mean values and standard deviations)

\begin{tabular}{|c|c|c|c|c|c|c|c|}
\hline \multirow{2}{*}{$\begin{array}{l}\text { Activity level }{ }^{*} \ldots \\
n \ldots \\
\text { RMR }\end{array}$} & \multicolumn{2}{|c|}{$\begin{array}{c}\text { Non-runners } \\
5\end{array}$} & \multicolumn{2}{|c|}{$\begin{array}{c}\text { Moderately } \\
\text { active runners } \\
9\end{array}$} & \multicolumn{2}{|c|}{$\begin{array}{c}\text { Very active } \\
\text { runners } \\
7\end{array}$} & \\
\hline & Mean & SD & Mean & SD & Mean & SD & \\
\hline $\mathrm{kJ} / \mathrm{min}$ & 3.43 & 0.29 & 3.47 & 0.62 & $3 \cdot 89$ & 0.41 & \\
\hline $\mathrm{kJ} / \mathrm{kg}$ per $\mathrm{h}$ & 3.85 & 0.38 & 3.97 & 0.53 & $4 \cdot 23$ & 0.32 & \\
\hline $\mathrm{kJ} / \mathrm{kg}$ FFM per $\mathrm{h}$ & $5 \cdot 23$ & 0.34 & $5 \cdot 10$ & $0 \cdot 71$ & $5 \cdot 10$ & 0.59 & \\
\hline
\end{tabular}

FFM, fat-free mass, estimated by underwater weighing.

No differences between groups were statistically significant.

* Moderately active, estimated maximal oxygen consumption $\left(\dot{V}_{\mathrm{O}_{2}, \max }\right)<58 \mathrm{ml} / \mathrm{kg}$ per min; very active, $\dot{V}_{\mathrm{O}_{2}, \max }>63 \mathrm{ml} / \mathrm{kg}$ per min.

Table 1). The very active runners, although significantly $(P<0.001)$ more fit by estimate of $\dot{V}_{\mathrm{O}_{2}, \max }$ (American College of Sports Medicine, 1986), did not run significantly further $(\mathrm{km} /$ week) than did the moderately active runners; however, they did run at a significantly faster pace. Two of the very active women were oligomenorrhoeic; no participant was amenorrhoeic.

\section{Energy balance}

Analysis of daily weight records confirmed that there were no significant net changes in body-weight between the first and final weeks of participation (Table 1). RMR expressed as $\mathrm{kJ} / \mathrm{min}$ and $\mathrm{kJ} / \mathrm{kg}$ (Table 2) increased slightly with the increase in activity, presumably reflecting the higher FFM of the runners (Ravussin \& Bogardus, 1989). Analysis of $14 \mathrm{~d}$ of taped diet records for each subject, distributed proportionately between weekdays and weekend days, indicated that both groups of runners tended to consume slightly more 
Table 3. Reported daily energy intake and expenditure of physically active women

(Mean values and standard deviations. Calculations are based on data provided by subjects in taperecorded diaries, and literature values for the energy values of foods and activities)

\begin{tabular}{|c|c|c|c|c|}
\hline $\begin{array}{l}\text { Activity level }{ }^{*} \ldots \\
n \ldots\end{array}$ & & $\begin{array}{c}\text { Non-runners } \\
5\end{array}$ & $\begin{array}{l}\text { Moderately active } \\
\text { runners } \\
9\end{array}$ & $\begin{array}{c}\text { Very active } \\
\text { runners } \\
7\end{array}$ \\
\hline \multicolumn{5}{|l|}{ Intake } \\
\hline \multirow[t]{2}{*}{$\mathrm{kJ}(\mathrm{kcal}) / \mathrm{d}$} & Mean & $7297(1744)$ & $8318(1988)$ & 8255 (1973) \\
\hline & SD & $1535(367)$ & $1838(439)$ & $1465(350)$ \\
\hline \multirow[t]{2}{*}{$\mathrm{kJ}(\mathrm{kcal}) / \mathrm{kg}$ per d } & Mean & $134 \cdot 7(32 \cdot 2)$ & $156.9(37.5)$ & $154 \cdot 8(37.0)$ \\
\hline & SD & $22 \cdot 3(5 \cdot 3)$ & $21 \cdot 5(5 \cdot 1)$ & $37 \cdot 9(9 \cdot 1)$ \\
\hline \multirow{2}{*}{$\mathrm{kJ}(\mathrm{kcal}) / \mathrm{kg}$ FFM per $\mathrm{d}$} & Mean & $182 \cdot 8(43 \cdot 7)$ & $205 \cdot 0(49 \cdot 0)$ & $182.0(43 \cdot 5)$ \\
\hline & $\mathrm{SD}$ & $30.8(7.4)$ & $35 \cdot 6(8 \cdot 5)$ & $40 \cdot 1(9 \cdot 6)$ \\
\hline \multicolumn{5}{|l|}{ Expenditure } \\
\hline \multirow{2}{*}{$\mathrm{kJ}(\mathrm{kcal}) / \mathrm{d}$} & Mean & $7473^{a}(1786)$ & $9251^{\text {ab }}(2211)$ & $10958^{\mathrm{b}}(2619)$ \\
\hline & $\mathrm{SD}$ & $872(208)$ & $2159(516)$ & $1367(327)$ \\
\hline \multirow{2}{*}{$\mathrm{kJ}(\mathrm{kcal}) / \mathrm{kg}$ FFM per $\mathrm{d}$} & Mean & $189 \cdot \mathrm{l}^{\mathrm{a}}(45-2)$ & $227 \cdot 6^{\mathrm{ab}}(54-4)$ & $242 \cdot 3^{\mathrm{b}}(57 \cdot 9)$ \\
\hline & SD & $29 \cdot 4(7.0)$ & $42 \cdot 7(10 \cdot 2)$ & $23.1(5.5)$ \\
\hline \multirow[t]{2}{*}{ Activity index (AI) } & Mean & $1 \cdot 50^{\mathrm{a}}$ & $1.84^{\mathrm{b}}$ & $1.98^{\mathrm{b}}$ \\
\hline & SD & $0 \cdot 15$ & 0.15 & $0 \cdot 16$ \\
\hline \multirow[t]{2}{*}{ Non-running AI } & Mean & $1 \cdot 50$ & $1 \cdot 66$ & 1.69 \\
\hline & $\mathrm{SD}$ & 0.15 & 0.14 & 0.08 \\
\hline \multicolumn{5}{|c|}{ Energy balance: intake-expenditure } \\
\hline \multirow[t]{2}{*}{$\mathrm{kJ}(\mathrm{kcal}) / \mathrm{d}$} & Mean & $-176^{a}(-42)$ & $-933^{\text {ab }}(-223)$ & $-2703^{b}(-646)$ \\
\hline & SD & $2026(484)$ & $895(214)$ & $1997(477)$ \\
\hline
\end{tabular}

FFM, fat-free mass; Activity index (AI), daily energy expenditure expressed as a multiple of resting metabolic rate; non-running $\mathrm{AI}$, activity index for all activities other than running.

a,b Means in horizontal rows with different superscript letters were significantly different $(P<0.05)$.

* Moderately active, estimated maximal oxygen consumption $\left(\dot{V}_{\mathrm{o}_{2}, \max }\right)<58 \mathrm{ml} / \mathrm{kg}$ per min; very active, $\dot{V}_{\mathrm{O}_{2}, \max }>63 \mathrm{ml} / \mathrm{kg}$ per $\min$.

energy, expressed as both $\mathrm{kJ} / \mathrm{d}$ and $\mathrm{kJ} / \mathrm{kg}$ per $\mathrm{d}$, than did the non-runners, although the differences were not significant due to high within-group variation (Table 3 ). When adjusted for FFM, the energy intakes of the non-runners and very active runners appeared to be identical.

Daily EE was calculated from taped diaries of 7-14 d of activity (Table 3), with the appropriate proportion of weekday and weekend reports. Coefficients of variation of calculated individual daily EE were neither reduced nor increased by increasing the number of days analysed beyond 7, so all activity records analysed are included in these figures. While differences in energy intakes were not found to be significant, calculated daily EE of the very active runners, expressed as both $\mathrm{kJ} / \mathrm{d}$ and $\mathrm{kJ} / \mathrm{kg}$ FFM per $\mathrm{d}$, was significantly higher than that of the non-runners. When expressed as AI, the daily EE for both groups of runners was significantly greater than that of the non-runners. As determined by NRAI, the very active runners appeared to be more active during the time that they were not running, although the difference falls just short of statistical significance $(P=0.05)$.

Energy balance was computed by subtracting calculated daily EE from calculated daily energy intake (Table 3). Participants were assumed to have remained in energy equilibrium, because body-weight was maintained. Women in the non-running group were close to balance, but the difference between the intake and expenditure of the very active runners was significantly more negative than that of the non-runners. The difference between intake and EE of the moderately active runners lay between those of the non-runners and very active runners, but was not significantly different from either. 


\section{Activity patterns}

Analysis of daily activity patterns (Fig. 1) in terms of gross classifications of activity shows that the runi $₫$ re tended to spend more time in more-active pursuits, such as standing and performing other strenuous exercise, while the non-runners tended to spend more time sitting and sleeping. Although only differences in time-period spent running were statistically significant, differences in amount of time spent sleeping $(P=0.07)$ and at other strenuous activities $(P=0.06)$ approached significance.

\section{Energy expenditure measurements}

Analysis of energy expended at fixed work loads (Table 4) shows no significant differences among groups when EE is expressed as $\mathrm{kJ} / \mathrm{min}$. Measurements of EE on the cycle ergometer were taken over a wider range of work loads for estimation of $\dot{V}_{\mathrm{O}_{\text {.max }}}$; however, only two are reported here because many of the non-runners were unable to continue pedalling past these levels. Sitting EE expressed as $\mathrm{kJ} / \mathrm{min}$ was slightly, though not significantly, increased in the moderately active and very active women.

Table 5 summarizes results of measurements made at work rates set by the individual. Although no statistically significant differences were seen in the variables, some interesting trends can be noted. In each case, the very active women tended to perform the tasks at intensities equal to or greater than those of the non-runners and to perform timed tasks slightly faster.

\section{DISCUSSION}

We present findings showing that although reported energy intakes of weight-stable female runners are slightly higher than those of sedentary peers, the magnitude of the increased intake of the runners is not commensurate with the calculated expenditure. The very active runners in the present study maintained body-weight on intakes calculated to be $2703 \mathrm{~kJ} / \mathrm{d}$ lower than expenditure. Under the same experimental conditions, the women who did not routinely exercise appeared to attain a balance between input and output. In addition, our findings suggest that the runners do not compensate for their strenuous activity by decreasing the duration or intensity of their other discretionary activities. There are several possible explanations for this apparent discrepancy between intake and output in the very active runners. These include: (1) problems inherent in the data collection methodologies, (2) problems associated with determination of EFACTs used to compute theoretical outputs, (3) possible increased efficiency of energy utilization in physically active women.

Most investigators agree that the methodologies used here to estimate energy balance are problematic (Durnin \& Brockaway, 1959; Buskirk et al. 1980; Schutz, 1981), estimates of total error being as high as $20 \%$ (Garrow, 1974). The total error is generated from errors in determination of energy intake, estimation of time at activities, indirect calorimetric measurement of energy expended at rest and activities, and by the use of literature energy factors. Assessment of the reliability of our values in contrast to other literature values may allow evaluation of the validity of our conclusions.

Although no method of estimating habitual intake in free-living persons is entirely satisfactory, the weighed food inventory or diary method employed in the present study has been considered the best available method (James et al. 1981; Marr \& Heady, 1986). In fact, a single $3 \mathrm{~d}$ food record has been declared by some researchers to be a reliable means of determining average energy intake of groups of subjects (Basiotis et al. 1987; Karkeck, 1987). That we have taken a mean of several such records, ranging over all the days of the week, should add to the validity of these data in estimating daily energy intake. Our reported intakes correspond quite closely with previous reports of energy intakes in women runners. Moore et al. (1983), in a study of high-density-lipoprotein-cholesterol levels in 


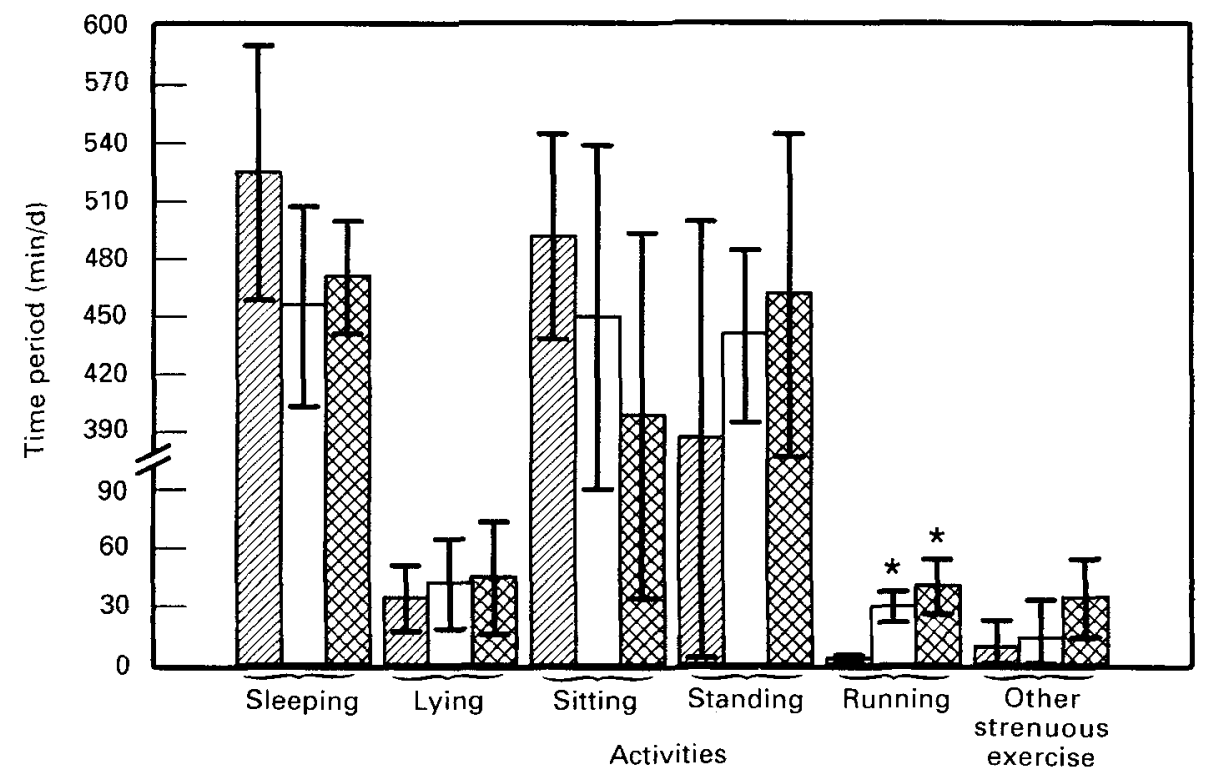

Fig. 1. Time-periods (min/d) spent by female $(\square \Delta)$ non-runners (NR), $\square$ ) moderately active runners (MAR; estimated maximal oxygen consumption $\left(\dot{V}_{O_{2} \text { max }}\right)<58 \mathrm{ml} / \mathrm{kg}$ per min), and (B) very active runners (VAR; estimated $V_{\mathrm{o}_{2}, \max }>63 \mathrm{ml} / \mathrm{kg}$ per min) in various activities through a $24 \mathrm{~h}$ period. Values are group means; standard deviations are represented by vertical bars. Significance of differences between groups by one-way ANOVA : sleeping, $P=0.07$; other exercise, $P=0.06$; running, $P<0.001$. No other differences between groups approached significance.

* Both groups of runners ran significantly more min/d than non-runners $(P<0.05)$.

Table 4. Energy expenditure measured at fixed power output $(P O)$

(Mean values and standard deviations)

\begin{tabular}{|c|c|c|c|c|c|c|}
\hline \multirow[t]{2}{*}{$\begin{array}{l}\text { Activity level* ... } \\
n \ldots\end{array}$} & \multicolumn{2}{|c|}{$\begin{array}{c}\text { Non-runners } \\
4\end{array}$} & \multicolumn{2}{|c|}{$\begin{array}{l}\text { Moderately } \\
\text { active runners } \\
9\end{array}$} & \multicolumn{2}{|c|}{$\begin{array}{c}\text { Very active } \\
\text { runners } \\
7\end{array}$} \\
\hline & Mean & $\mathrm{SD}$ & Mean & SD & Mean & SD \\
\hline \multicolumn{7}{|l|}{ Cycle ergometer } \\
\hline $\mathrm{PO}: 300 \mathrm{~kg} \cdot \mathrm{m} / \mathrm{min}(\mathrm{kJ} / \mathrm{min})$ & $19 \cdot 0$ & $0 \cdot 8$ & $17 \cdot 9$ & $0 \cdot 9$ & $18 \cdot 5$ & $1 \cdot 5$ \\
\hline PO: $400 \mathrm{~kg} . \mathrm{m} / \mathrm{min}(\mathrm{kJ} / \mathrm{min})$ & $23 \cdot 4$ & $1 \cdot 3$ & $22 \cdot 6$ & 0.8 & $23 \cdot 0$ & $1 \cdot 6$ \\
\hline Sitting $(\mathrm{kJ} / \mathrm{min})$ & $4 \cdot 5$ & 0.7 & $4 \cdot 9$ & $0 \cdot 7$ & $4 \cdot 9$ & $1 \cdot 3$ \\
\hline
\end{tabular}

No differences between groups were statistically significant.

* Moderately active, estimated maximal oxygen consumption $\left(\dot{V}_{\mathrm{O}_{2}, \text { max }}\right)<58 \mathrm{ml} / \mathrm{kg}$ per min; very active, $\dot{V}_{\mathrm{o}_{2}, \max }>63 \mathrm{ml} / \mathrm{kg}$ per min.

physically active women, reported intakes of $7385 \mathrm{~kJ} / \mathrm{d}$ in runners and $7280 \mathrm{~kJ} / \mathrm{d}$ in sedentary controls. Lampe et al. (1986), in a study of iron status in women marathon runners, reported an average energy intake of $8012 \mathrm{~kJ} / \mathrm{d}$. Recently, Drinkwater et al. (1984) and Marcus et al. (1985) have reported intakes of 8222 and $7176 \mathrm{~kJ} / \mathrm{d}$ in eumenorrhoeic women running 40 and $94 \mathrm{~km} /$ week respectively.

There is no consensus regarding which of the traditional methods of estimating average daily EE is most accurate, although the use of activity diaries and specific energy factors 
Table 5. Energy expenditure of physically active women measured at intensities selected by the individual

(Mean values and standard deviations)

\begin{tabular}{|c|c|c|c|c|c|c|}
\hline \multirow[t]{2}{*}{$\begin{array}{l}\text { Activity level* } \ldots \\
n \ldots\end{array}$} & \multicolumn{2}{|c|}{$\begin{array}{c}\text { Non-runners } \\
4\end{array}$} & \multicolumn{2}{|c|}{$\begin{array}{c}\text { Moderately } \\
\text { active runners } \\
9\end{array}$} & \multicolumn{2}{|c|}{$\begin{array}{c}\text { Very active } \\
\text { runners } \\
7\end{array}$} \\
\hline & Mean & SD & Mean & SD & Mean & $\mathrm{SD}$ \\
\hline \multicolumn{7}{|l|}{ Milling around } \\
\hline $\mathrm{kJ} / \mathrm{min}$ & $6 \cdot 7$ & $1 \cdot 1$ & $8 \cdot 1$ & $1 \cdot 7$ & $8 \cdot 4$ & 1.7 \\
\hline $\mathrm{kJ} / \mathrm{kg} \mathrm{FFM}$ per $\mathrm{h}$ & $10 \cdot 1$ & $2 \cdot 1$ & 11.9 & 1.9 & $11 \cdot 1$ & $1 \cdot 7$ \\
\hline \multicolumn{7}{|l|}{ Walk - flat surface } \\
\hline $\mathrm{kJ} / \mathrm{min}$ & $10 \cdot 7$ & $1 \cdot 2$ & $11 \cdot 4$ & $3 \cdot 7$ & $12 \cdot 4$ & $2 \cdot 4$ \\
\hline $\mathrm{kJ} / \mathrm{kg}$ FFM per h & $16 \cdot 2$ & $3 \cdot 0$ & 16.7 & $4 \cdot 4$ & $16 \cdot 3$ & $3 \cdot 2$ \\
\hline seconds/round trip & $41 \cdot 7$ & $6 \cdot 7$ & $43 \cdot 4$ & $13 \cdot 0$ & $39 \cdot 3$ & $3 \cdot 2$ \\
\hline \multicolumn{7}{|l|}{ Walk - stairs } \\
\hline $\mathrm{kJ} / \mathrm{min}$ & $24 \cdot 9$ & 48 & $24 \cdot 6$ & $4 \cdot 7$ & $29 \cdot 2$ & $4 \cdot 6$ \\
\hline seconds/round trip & $36 \cdot 0$ & $9 \cdot 6$ & $32 \cdot 3$ & $5 \cdot 0$ & 30.0 & $2 \cdot 5$ \\
\hline
\end{tabular}

FFM, fat-free mass; seconds/round trip, time to complete one trip through prescribed course.

No differences between groups were statistically significant.

* Moderately active, estimated maximal oxygen consumption $\left(\dot{V}_{\mathrm{O}_{2}, \max }\right)<58 \mathrm{ml} / \mathrm{kg}$ per min; very active, $\dot{V}_{\mathrm{O}_{2}, \max }>63 \mathrm{ml} / \mathrm{kg}$ per min.

has been widespread. Acheson et al. (1980), in a study comparing methodologies, found the diary method to be no more accurate than use of heart rates to estimate average daily EE, when compared with measured energy intake adjusted for changes in body composition. Geissler et al. (1986), in a study comparing the diary method with continuous $24 \mathrm{~h}$ measurements of EE in a respiration chamber, found individual discrepancies as great as $\pm 1674 \mathrm{~kJ} / \mathrm{d}$, but concluded that the factorial method was adequate for predicting population EE. However, Warwick et al. (1988), making a similar comparison between the Food and Agriculture Organization/World Health Organization/United Nations University (1985) factorial method of EE determination and $24 \mathrm{~h}$ EE measured in a respiratory chamber, found individual values to agree within $5 \%$ when measured basal MR was used in the factorial calculation.

The magnitude of the standard deviations of individual balances found by Warwick et al. (1988) (2.03 MJ/d for women) was the same as that found in our study for nonrunners $(2.03 \mathrm{MJ} / \mathrm{d})$ and very active runners $(2.00 \mathrm{MJ} / \mathrm{d})$. Other researchers, using similar methodologies in studies which have yielded close agreement between group mean energy intake and expenditure have also reported wide ranges of individual balances (Edholm et al. 1955; Acheson et al. 1980).

Estimation of total daily resting energy requirement from individual 10 min measures is difficult, the accuracy of the estimate depending critically on the reproducibility of the measure (Garrow, 1974). Using methodologies similar to ours, Garby \& Lammert (1984) found sequential measures of the same individual to vary by $3.8 \%$, and measurements made between weeks varied by $3 \cdot 2 \%$. Our replicate measures, on average, varied by $4 \cdot 4$ (SD 1.6$) \%$ in non-runners and 4.6 (SD 2.1 ) \% in runners. Measured mean RMR values of the three groups are practically identical to those predicted by Durnin \& Passmore (1967) for women of comparable body composition. Using another FFM-based equation (Ravussin \& Bogardus, 1989) using group mean FFM values to predict RMR, gives values which average $4.7 \%$ more than measured in non-runners and 5.7 and $4.1 \%$ more than measured 
in moderately active and very active runners respectively. Thus, while use of resting EE measured on two occasions to represent average daily resting energy costs no doubt introduces some error into our estimate of average total $\mathrm{EE}$, we find no evidence to suggest that calculated total EE of one group was affected to a significantly greater extent than that of the other groups.

Use of literature values for estimating the energy cost of activities in the diary method could result specifically in overestimation of daily EE for two reasons. First, the use of energy values derived from discrete measurements to estimate the expenditure of serial activities may fail to account for transitions in EE from one activity to the next, and may, thus, give a higher energy value than is appropriate for those transition periods. Second, literature values could be overvalued for this population. Those values used were derived from published reports of EE measured by indirect calorimetry, primarily in sedentary men. Borel et al. (1984), studying EE as determined by the factorial method in both male and female college students, found the discrepancy between the intake-balance method and the diary method to be greater in women $(4.79 \%)$ than in men $(1.65 \%)$. These investigators suggested that this discrepancy may illustrate the inappropriateness of using literature values derived from men for calculation of EE in women. In addition, significant cultural differences in EE for specific activities have been shown by Dieng et al. (1980) and Geissler \& Aldouri (1985). Garrow (1974) also points out that individual variation in these values may be greater than $20 \%$. Comparison of literature values with RMR multiples derived from the measurements made in the present study, however, (Table 6) shows that in each case the literature value used was slightly lower than our measured value. Calculation of estimated daily EE using individually measured values for the appropriate activities would result in increased, not decreased, theoretical EE in nineteen of twenty-one participants in the present study.

Thus, comparison of the variation in our methodology with that reported in the literature for similar measures suggests our data collection to be at least as precise as others. All methods were applied uniformly across all groups and all subjects were reasonably compliant, giving no reason to suspect that one group was more prone to errors than another. Thus, we feel that, despite inherent methodological errors, the relative relationships shown in our data are valid.

The notion of differences in metabolic efficiency among individuals suggested by these findings is not new; Widdowson (1947), in her report of a survey of schoolchildren in Great Britain, found two-fold differences in intake and suggested that '... some are very much more efficient machines than others'. Edmundson (1977), 30 years later, found that East Java workers with low energy intakes were as productive as those with high intakes; and that efficiency, expressed as the ratio of individual expenditure:intake, varied inversely with the degree of undernutrition. He concluded that '... the external work value of food may depend upon who is eating the food.'

However, possible sites for this improvement in efficiency are more elusive. Shifts in fuel usage with exercise could account for some conservation. Active individuals are known to increase their ability to store glycogen (Brooks \& Fahey, 1984), and glycogen storage has been reported to require only $5 \%$ of the ingested energy, whereas storage of the same fuel as triacylglycerol requires $20 \%$ (Flatt, 1978). In addition, these active individuals have a smaller fat mass, suggesting smaller fat cells (Depres et al. 1984). Triacylglycerol turnover has been shown to be depressed in smaller fat cells (Bjorntorp, 1985), and such a metabolic adaptation could conserve some energy. Other possible sites for change in energy transformation include 'futile cycles' (Newsholme, 1978), protein turnover (Bjorntorp, 1985), and activity of the sympathetic nervous system. Output of norepinephrine and epinephrine has been reported to be lower in trained individuals in response to an exercise 
Table 6. Comparison of measured and literature values for the energy cost of selected activities of physically active women

(Mean values and standard deviations; all values are expressed as multiples of resting metabolic rate)

\begin{tabular}{|c|c|c|c|c|c|c|c|c|c|}
\hline \multirow{3}{*}{$\begin{array}{l}\text { Activity level* } \ldots \\
n \ldots\end{array}$} & \multicolumn{8}{|c|}{ Measured } & \multirow{3}{*}{$\begin{array}{c}\text { Literature } \\
\text { values } \dagger\end{array}$} \\
\hline & \multicolumn{2}{|c|}{$\begin{array}{c}\text { Non-runners } \\
4\end{array}$} & \multicolumn{2}{|c|}{$\begin{array}{l}\text { Moderately } \\
\text { active runners } \\
9\end{array}$} & \multicolumn{2}{|c|}{$\begin{array}{c}\text { Very active } \\
\text { runners } \\
7\end{array}$} & \multicolumn{2}{|c|}{$\begin{array}{c}\text { All } \\
\text { subjects } \\
20\end{array}$} & \\
\hline & Mean & SD & Mean & SD & Mean & SD & Mean & SD & \\
\hline Sitting & $1 \cdot 3$ & $0 \cdot 3$ & $1 \cdot 4$ & 0.2 & $1 \cdot 3$ & $0 \cdot 2$ & $1 \cdot 3$ & $0 \cdot 2$ & $1 \cdot 2$ \\
\hline Milling around & 1.9 & 0.4 & $2 \cdot 4$ & 0.4 & $2 \cdot 2$ & 0.4 & $2 \cdot 2$ & 0.4 & $1 \cdot 7$ \\
\hline Walk - flat & 3.0 & 0.5 & $3 \cdot 3$ & 0.6 & $3 \cdot 2$ & $0 \cdot 3$ & $3 \cdot 2$ & 0.5 & 2.9 \\
\hline
\end{tabular}

No differences between groups were statistically significant.

* Moderately active, estimated maximal oxygen consumption $\left(\dot{V}_{\mathrm{O}_{2}, \max }\right)<58 \mathrm{ml} / \mathrm{kg}$ per min; very active, $\dot{V}_{\mathrm{O}_{,}, \mathrm{mux}}>63 \mathrm{ml} / \mathrm{kg}$ per min.

Literature values from Gorsky \& Calloway (1983).

bout (Thompson \& Blanton, 1987) and following ingestion of a meal (LeBlanc et al. $1984 \mathrm{a}$ ). The effects of some of these adaptations, however, should be reflected in changes in RMR. We found no evidence of such changes in the measured RMR of the runners in the present study when adjusted for differences in FFM. Moreover, these adaptations alone would not be sufficient to explain an energy discrepancy of over $2700 \mathrm{~kJ} / \mathrm{d}$.

Finally, it is not clear if a capacity for change in the efficiency of energy utilization is a result of adaptation to chronically high levels of activity or if genetic circumstances such as those which permit working at high intensities also make the physically active woman a 'more efficient machine'. Our method of determining activity groups by $\dot{V}_{\mathrm{O}_{2}, \max }$ may have accentuated this point. Maximal aerobic power, although considered a criterion of physical fitness (American College of Sports Medicine, 1986), is primarily genetically determined and training can only augment that potential by 10-20\% (Brooks \& Fahey, 1984). Other factors important in athletic performance, such as maximal muscle power and distribution of slow-twitch muscle fibres, have also been shown to have genetic determinants (Klissouras, 1978). Thus, any apparent increase in the efficiency of energy utilization in our very active runners may be the result of a combination of genetic potential and training. The precise mechanisms of expression are not clear and may not be detectable with traditional indirect calorimetric methods.

The authors wish to thank Dr Mark Hudes for his assistance with the activity data analysis; Mary Kathleen Kelley for her assistance with the dietary analysis; Wylie Liu for her assistance with the underwater weighing; and all the participants, whose interest and cooperation made the study possible. The study was supported in part by a PHS Biomedical Research Support Grant.

\section{REFERENCES}

Acheson, K. J., Campbell, I. T., Edholm, O. G., Miller, D. S. \& Stock, M. J. (1980). The measurement of daily energy expenditure an evaluation of some techniques. American Journal of Clinical Nutrition 33, $1155-1164$.

American College of Sports Medicine (1986). Guidelines for Exercise Testing and Prescription, p. 43. Philadelphia: Lea \& Febiger

Apfelbaum, J., Bostarron, J. \& Lacatis, D. (1971). Effect of calorie restriction and excessive caloric intake on energy expenditure. American Journal of Clinical Nutrition 24, 1405-1409. 
Astrand, P.-O. \& Rodahi, K. (1970). Textbook of Work Physiology. New York: McGraw-Hill Book Co.

Basiotis, P. P., Welsh, S. O., Cronin, F. J., Kelsay, J. L. \& Mertz, W. (1987). Number of days of food intake records required to estimate individual and group nutrient intakes with defined confidence. Journal of Nutrition 117, $1638-1641$.

Behnke, A. R. \& Wilmore, J. H. (1974). Evaluation and Regulation of Body Build and Composition. Englewood Cliffs, NJ: Prentice Hall.

Bingham, S. A., Goldberg, G. R., Coward, W. A., Prentice, A. M. \& Cummings, J. H. (I989). The effect of exercise and improved physical fitness on basal metabolic rate. British Journal of Nutrition 61, $155-173$.

Bjorntorp, P. (1985). Obesity and exercise. In Biochemistry of Exercise, vol. 4A, pp. 260-269 [I. Poortmans and N. Niset, editors]. Baltimore: University Park Press.

Bleiberg, F., Brun, T. A., Goihman, S. \& Lippman, D. (1981). Food intake and energy expenditure of male and female farmers from Upper Volta. British Journal of Nutrition 45, 505-515.

Borel, M. J., Riley, R. E. \& Snook, J. T. (1984). Estimation of energy expenditure and maintenance energy requirements of college-age men and women. American Journal of Clinical Nutrition 40, $1264-1272$.

Briggs, G. M. \& Calloway, D. H. (1979). Bogert's Nutrition and Physical Fitness, 10th ed. Philadelphia: W. B. Saunders.

Brooks, G. A. \& Fahey, T. D. (1984). Exercise Physiology. New York: John Wiley \& Sons.

Buskirk, E. R., Hodgson, J. \& Blair, D. (1980). Assessment of daily energy balance: Some observations on the methodology for indirect determinations of cnergy intake and expenditure. In Assessment of Energy Metabolism in Health and Disease, Report of First Ross Conference on Medical Research, pp. 113-117 [J. M. Kinney, editor]. Columbus, Ohio: Ross Laboratories.

Davis, J. R., Tagliaferro, A. R., Kertzer, R., Gerardo, T., Nichols, J. \& Wheeler, J. (1983). Variations in dietaryinduced thermogenesis and body fatness with aerobic capacity. European Journal of Applied Physiology 50, $319-329$

de Guzman, M. P. E., Cabrera, J. P., Yuchingtat, G. P., Abanto, Z. U. \& Guarano, A. L. (1984). A study of the energy expenditure, dietary intake and pattern of daily activity among various occupational groups. II. Laguna rice farmers. Philippine Journal of Nutrition 37, 163-174.

Depres, J. P., Bouchard, C., Savard, R., Tremblay, A., Marcotte, M. \& Theriault, G. (1984). The effect of a $20-$ week endurance training program on adipose-tissue morphology and lipolysis in men and women. Metabolism 33, 235-239.

Deuster, P. A., Kyle, S. B., Moser, P. B., Vigersky, R. A., Singh, A. \& Shoomaker, E. B. (1986). Nutritional survey of highly trained women runners. American Journal of Clinical Nutrition 45, 954-962.

Dieng, K., Lemonnier, D., Bleiberg, F. \& Brun, T. A. (1980). Differences in the rate of energy expenditure of resting activities between European and African men. Nutrition Reports International 21, 183-187.

Drinkwater, B. L., Nilson, K., Chesnut, C. H. III, Bremner, W. J., Shainholtz, S. \& Southworth, M. (1984). Bone mineral content of amenorrheic and eumenorrheic athletes. New England Journal of Medicine 311, $277-281$.

Durnin, J. V. G. A. \& Brockaway, J. M. (1959). Determination of the total daily energy expenditure in man by indirect calorimetry: assessment of the accuracy of a modern technique. British Journal of Nutrition 13, 41-53.

Durnin, J. V. G. A. \& Passmore, R. (1967). Energy, Work and Leisure. London: Heineman Educational Books Ltd.

Edholm, O. G., Fletcher, J. G., Widdowson, E. M. \& McCance, R. A. (1955). The energy expenditure and food intake of individual men. British Journal of Nutrition 9, 286-300.

Edmundson, W. (1977). Individual variations in work output per unit energy intake in East Java. Ecology of Food and Nutrition 6, 147-151.

Flatt, J. P. (1978). The biochemistry of energy expenditure. In Recent Advances in Obesity Research, vol. 2, pp. 211-228 [G. A. Bray, editor]. Westport, CT: Technomic Publishing Company Inc.

Food and Agriculture Organization/World Health Organization/United Nations University (1985). Joint Report on Energy and Protein Requirements. Technical Report Series no. 724. Geneva: WHO.

Garby, L. \& Lammert, O. (1984). Within-subjects between-days-and-weeks variation in energy expenditure at rest. Human Nutrition: Clinical Nutrition 38C, 395-397.

Garrow, J. S. (1974). Energy Balance and Obesity in Man. New York: American Elsevier.

Geissler, C. A. \& Aldouri, M. S. H. (1985). Racial differences in the energy cost of standardized activities. Annals of Nutrition and Metabolism 29, 40 47.

Geissler, C. A., Dzumbira, T. M. O.\& Noor, M. I. (1986). Validation of a field technique for the measurement of energy expenditure : factorial method versus continuous respirometry. American Journal of Clinical Nutrition 44, 596-602.

Gorsky, R. D. \& Calloway, D. H. (1983). Activity pattern changes with decreases in food energy intake. Human Biology 55, 577-586.

Howley, E. T. \& Glover, M. E. (1974). The caloric cost of running and walking one mile for men and women. Medicine and Science in Sports 6, 235-237.

James, W. P. T., Bingham, S. A. \& Cole, T. J. (1981). Epidemiological assessment of dietary intake. Nutrition and Cancer 2, 203-212.

Karkeck, J. M. (1987). Improving the use of dietary survey methodology. Journal of the American Dietetic Association 87, 869871 . 
Keys, A., Brozek, J., Henschel, A., Mickelsen, O. \& Taylor, H. S. (1950). The Biology of Human Starvation, vol. 1. Minneapolis: University of Minnesota Press.

Klissouras, V. (1978). Prediction of athletic performance: genetic considerations. In Exercise Physiology, Fitness and Performance Capacity Studies, vol. 4, pp. 3-17 [F. Landry and W. A. R. Orban, editors]. Miami: Symposia Specialists Inc.

Lampe, J. W., Slavin, J. L. \& Apple, F. S. (1986). Poor iron status of women runners training for a marathon. International Journal of Sports Medicine 7, 111-114.

LeBlanc, J., Diamond, P., Cote, J. \& Labrie, A. (1984a). Hormonal factors in reduced postprandial heat production of exercise-trained subjects. Journal of Applied Physiology 56, 772-776.

LeBlanc, J., Mercier, P. \& Samson, P. (1984b). Diet-induced thermogenesis with relation to training state in female subjects. Canadian Journal of Physiology and Pharmacology 62, 334-337.

McGuire, J. S. \& Torun, B. (1984). Dietary energy intake and energy expenditure of women in rural Guatamala. In Protein-Energy Requirement Studies in Developing Countries: Results of International Research, pp. 175-186 [W. M. Rand, R. Uauy and N. S. Scrimshaw, editors]. Geneva: United Nations University.

Marcus, R., Cann, C., Madvig, P., Minkoff, J., Goddard, M., Bayer, M., Martin, M., Gaudiani, L., Haskell, W. \& Genant, H. (1985). Menstrual function and bone mass in elite women distance runners: endocrine and metabolic features. Annals of Internal Medicine 102, 158-163.

Marr, J. W. \& Heady, J.A. (1986). Within- and between-person variation in dietary surveys: number of days needed to classify individuals. Human Nutrition: Applied Nutrition 40A, 347-364.

Moore, C. E., Hartung, G. H., Mitchell, R. E., Kappus, C. M. \& Hinderlitter, J. (1983). The relationship of exercise and diet on high-density lipoprotein cholesterol levels in women. Metabolism 32, 189-196.

Murphy, S. P. (1984). Dietary correlates of trace element status for young women in NHANES II. PhD Thesis, University of California, Berkeley.

Myerson, M., Gutin, B., Warren, M., May, M., Contento, I., Lee, M., Pierson, R. \& Pi-Sunyer, F. (1987). Energy balance of amenorrheic and eumenorrheic runners. Medicine and Science in Sports and Exercise 19, Suppl., S37 Abstr.

Newsholme, E. A. (1978). Substrate cycles: their metabolic, energetic and thermic consequences in man. In Biochemical Society Symposia, vol. 43, pp. 183-205 [P. B. Garland and C. N. Hales, editors]. London: Biochemical Society.

Nie, N. H., Hull, C. H., Jenkins, J. G., Steinbrenner, K. \& Bent, D. H. [editors] (1983). SPSS-X: Statistical Package for the Social Sciences. New York: McGraw-Hill Book Co.

Norgan, N. G., Ferro-Luzzi, A. \& Durnin, J. V. G. A. (1974). The energy and nutrient intake and the energy expenditure of 204 New Guinean adults. Philosophical Transactions of the Royal Society of London Series B 268, $309-348$

Passmore, R. \& Durnin, J. V. G. A. (1955). Human energy expenditure. Physiological Reviews 35, 801840.

Poehlman, E. T., Melby, C. L. \& Badylak, S. F. (1988). Resting metabolic rate and postprandial thermogenesis in highly trained and untrained males. American Journal of Clinical Nutrition 47, 793-798.

Prentice, A. M. (1984). Adaptations to long-tcrm low energy intake. In Energy Intake and Activity: Current Topics in Nutrition and Disease, vol. 11, pp. 3-31 [E. Pollitt and P. Amante, editors]. New York: Alan R. Liss Inc.

Ravussin, E. \& Bogardus, C. (1989). Relationship of genetics, age and physiological fitness to daily energy expenditure and fuel utilization. American Journal of Clinical Nutrition 49, 968-973.

Schutz, Y. (1981). Use of non-calorimetric techniques to assess energy expenditure in man. In Recent Advances in Obesity Research, vol. 3, pp. 153-158 [P. Bjorntorp, M. Cairella and A. N. Howard, editors]. Westport, CT: Technomic Publishing Company Inc.

Siri, W. E. (1956). Gross composition of the body. In Advances in Biological and Medical Physics, vol. 4, pp. 239-280 [J. H. Lawrence and C. A. Tobias, editors]. New York: Academic Press.

Solomon, S. J., Kurzer, M. S. \& Calloway, D. H. (1982). Menstrual cycle and basal metabolic rate in women. American Journal of Clinical Nutrition 36, 611616.

Thompson, J. K. \& Blanton, P. (1987). Energy conservation and exercise dependence: a sympathetic arousal hypothesis. Medicine and Science in Sports and Exercise 19, 91-99.

Todd, K. S., Hudes, M. \& Calloway, D. H. (1983). Food intake measurement: problems and approaches American Journal of Clinical Nutrition 37, 139-146.

Warwick, P. M., Edmundson, H. M. \& Thomson, E. S. (1988). Prediction of energy expenditure: simplified $\mathrm{FAO} / \mathrm{WHO} / \mathrm{UNU}$ factorial method vs continuous respirometry and habitual energy intake. American Journal of Clinical Nutrition 48, 1188-1196.

Weir, J. B. deV. (1949). New methods for calculating metabolic rate with special reference to protein metabolism. Journal of Physiology 109, 1-9.

Widdowson, E. M. (1947). A Study of Individual Children's Diets. Medical Research Council Special Report Series no. 257. London: H.M. Stationery Office.

Wilmore, J. H. (1969). A simplified method for the determination of residual lung volume. Journal of Applied Physiology 27, 96-100. 
Appendix. Activity codes and associated energy factors (EFACTs)

(Literature sources in parentheses. EFACT multiplied by individual's resting metabolic rate yields the energy $(k J)$ expended for the activity)

\begin{tabular}{|c|c|c|c|c|c|}
\hline Code & Activity & EFACT & Code & Activity & EFACT \\
\hline 01 Lie & Sleeping & $0.9\left(^{*}\right)$ & 43 & Housework & $3.7\left(^{*}\right)$ \\
\hline 02 & Rest & $1.0\left(^{*}\right)$ & 44 Stand & Stretch/yoga & $1.4(\dagger)$ \\
\hline 03 & Read & $1.0(\dagger)$ & 45 & Walk flat & $2.9(*)$ \\
\hline 04 & Write & $1 \cdot 1(\dagger)$ & 46 & Walk downhill & $3.5(\dagger)$ \\
\hline 05 & Sex & $2 \cdot 9(\dagger)$ & 47 & Walk downstairs & $3.5(\dagger)$ \\
\hline 06 & Toss/turn & $1 \cdot 1(\dagger)$ & 48 & Walk uphill & $6.5\left(^{*}\right)$ \\
\hline 07 & Watch TV & $1.0(\dagger)$ & 49 & Walk upstairs & $8 \cdot 0(\dagger)$ \\
\hline 08 & Talk & $1 \cdot 0(\dagger)$ & 50 & Walk fast & $3.5\left(^{*}\right)$ \\
\hline 09 & Massage & $1 \cdot 0(* \mp)$ & 51 & Walk with load & $3.7\left(^{*}\right)$ \\
\hline $15 \mathrm{Sit}$ & Inactive & $1 \cdot 2\left(^{*}\right)$ & 52 & Walk - eating & $2 \cdot 9(\dagger)$ \\
\hline 16 & Active & $1.4(* q)$ & 53 & Hike & $5 \cdot 0(\dagger)$ \\
\hline 17 & Read & $1 \cdot 2\left(^{*}\right)$ & 54 & Tennis & $6.0(*)$ \\
\hline 18 & Talk & $1.2(\dagger)$ & 55 & Bicycle & $60(*)$ \\
\hline 19 & Write & $1.4\left(^{*}\right)$ & 56 & Dance: exercise & $5 \cdot 0(t)$ \\
\hline 20 & Type & $1.7\left(^{*}\right)$ & 57 & Dance: social & $5 \cdot 0(\dagger)$ \\
\hline 21 & Eat & $1.4\left(^{*}\right)$ & 59 & Swim & $9 \cdot 4\left(^{*}\right)$ \\
\hline 22 & Drive & $2 \cdot 1(\dagger)$ & 60 Sit & Row & $6.5(\$)$ \\
\hline 23 & Games & $1.7(*)$ & 61 Stand & Calisthenics & $5 \cdot 0(\dagger)$ \\
\hline 24 & TV/movie & $1 \cdot 2(\dagger)$ & 62 & Aerobics & $6.6(\|)$ \\
\hline 25 & Stretch/yoga & $1.4(\dagger)$ & 63 Run & $3.7-4.3 \mathrm{~min} / \mathrm{km}$ & $13 \cdot 8(+)$ \\
\hline 26 & Office work & $1.4(*)$ & 64 & $4.44 .9 \mathrm{~min} / \mathrm{km}$ & $12 \cdot 6(+)$ \\
\hline 27 & Sing & $1.4(\dagger)$ & 65 & $5.0-5.5 \mathrm{~min} / \mathrm{km}$ & $11.7(+)$ \\
\hline 28 & Piano & $2 \cdot 3\left(^{*}\right)$ & 66 & $5.6-6.1 \mathrm{~min} / \mathrm{km}$ & $9 \cdot 8(+)$ \\
\hline 29 Sit & Dress & $1.4(+T)$ & 67 & $6.2-6.7 \mathrm{~min} / \mathrm{km}$ & $8 \cdot 1(t)$ \\
\hline 30 Stand & Dress & $2.9\left(^{*}\right)$ & 68 Run & $>6.7 \mathrm{~min} / \mathrm{km}$ & $8 \cdot 1(+)$ \\
\hline 31 & Inactive & $1.4(\dagger)$ & 69 & Very hilly & $150(\dagger \uparrow)$ \\
\hline 32 & Active & $1.7(\dagger)$ & 70 Stand & Gardening & $2.9(*)$ \\
\hline 33 & Talk & $1.4(\dagger)$ & 71 & Lift weights & $7.0(*)$ \\
\hline 34 & Write & $1.7(\dagger)$ & 72 & Move furniture & $3 \cdot 7(\dagger)$ \\
\hline 35 & Cook & $1.9\left(^{*}\right)$ & 73 Sit & Motorcycle & $2 \cdot 8(\|)$ \\
\hline 36 & Dishes & $2 \cdot 7\left(^{*}\right)$ & 74 Stand & Pet care & $3.7(+9)$ \\
\hline 37 & Eat & $1.7(\dagger)$ & 75 & Drafting & $\mathrm{l} \cdot 7(\S)$ \\
\hline 38 & Mill around & $1.7(\dagger)$ & 77 Run & Upstairs & $15 \cdot 0(\dagger)$ \\
\hline 39 & Personal care & $2.9\left(^{*}\right)$ & 78 Stand & Child care & $4 \cdot 0\left(^{*}\right)$ \\
\hline 40 & Shopping & $1.7(\dagger)$ & 80 Kneel & & $1.4(\dagger)$ \\
\hline 41 & Office work & $1.7(*)$ & 81 Stand & Windsurf & $8.5(+5)$ \\
\hline 42 & Party & $1.8(\dagger)$ & & & \\
\hline
\end{tabular}

* Briggs \& Calloway (1979).

$\dagger$ Gorsky \& Calloway (1983).

I Howley \& Glover (1974) (using RMR calculated per Durnin \& Passmore (1967)).

\$ Durnin \& Passmore (1967).

\| Passmore \& Durnin (1955) (using RMR calculated per Durnin \& Passmore (1967)).

- Deduced from source indicated. 